\title{
Pesquisa Científica como Eixo Integrador da Formação e Prática Médica
}

\author{
Scientific Research as an Integrating Axis \\ between Medical Training and Practice
}

Marisa Palácios ${ }^{1}$

\begin{abstract}
Segundo nossa Constituição Federal, as universidades brasileiras devem obedecer ao princípio da indissociabilidade entre ensino, pesquisa e extensão. Entretanto, embora esta indissociabilidade não seja de fato contestada, vemos com maior frequência ênfases em um ou outro componente desse tripé, e apenas raras vezes a discussão sobre processos de ensino-aprendizagem e de cuidado associada à das pesquisas. Geralmente, estas são ligadas à produção relacionada com a pós-graduação estrito senso, em particular com o doutorado. No mundo acadêmico em geral, a moeda corrente é o artigo científico, e é esta produção que proporciona inclusive ganhos monetários e simbólicos adicionais.
\end{abstract}

Essa valorização acentuada da pesquisa tem gerado grande aumento da produção científica brasileira tanto em quantidade como em qualidade. Um indicador desse crescimento é a participação brasileira na produção científica internacional, por meio de artigos científicos publicados em revistas internacionais e da internacionalização de nossos periódicos. Recentemente, o governo brasileiro tem oferecido incentivos à realização de estágios em universidades no exterior de vários modos e níveis, em graduação, pós-graduação ou pós-doutorado, o que certamente trará maior visibilidade internacional para a nossa produção acadêmica nos próximos anos. A estratégia de conquistar o mundo começa a ser concretizada com nossa participação, em igualdade de condições, em algumas mesas de debates acadêmicos internacionais. A internacionalização, entretanto, não se refere apenas à facilidade nas comunicações e à intensificação das trocas comerciais, concretas ou simbólicas, que alguns veem como um processo de cooperação. De fato, a internacionalização também se refere à competição entre Estados. Nesta perspectiva, é preciso examinar o processo de produção de saberes em um contexto que nos permita dar um salto de qualidade e de competência em nossas pesquisas.

Entendo que é desta forma que se deve refletir sobre como a graduação e a extensão devem interagir com a pesquisa, associando a produção do conhecimento às nossas realidades, transformando a questão da formação científica médica no eixo articulador entre pesquisa, ensino e extensão. Não se forma um pesquisador de ponta só no doutorado. Ele tem que começar a ser formado na graduação. E esta formação demanda que se supere um modelo que pode banalizar a própria pesquisa, quando seu "ensino" se circunscreve ao ensino de algumas técnicas de pesquisa ou à participação pontual e mecânica em alguma pesquisa já iniciada.

A boa formação científica, na compreensão e no uso dos diferentes métodos, possibilita também uma leitura crítica da produção publicada nas revistas científicas. Assim, estaremos de fato contemplando o preconizado no artigo 43 da Lei de Diretrizes e Bases da Educação Nacional sobre as finalidades da educação superior: "I. estimular a criação cultural e o desenvolvimento do espírito científico e do pensamento reflexivo"11 (Brasil, 2010). 
Para uma formação científica com espírito crítico, é fundamental que a formação não apenas inclua os conceitos básicos acerca da ciência e dos métodos de sua produção, mas igualmente exija alguma experiência em pesquisa também. Assim, o papel da graduação abrindo espaço de participação em pesquisa como iniciação científica é fundamental.

Não podemos pensar em desenvolver pesquisa sem um entrelaçamento forte com o ensino para a formação de pesquisadores e profissionais críticos, assim como a extensão que impõe uma dimensão ética fundamental. Nossos sujeitos/objetos de pesquisa são aqueles a quem dirigimos nossos serviços, razão maior de nossa profissão. Tanto ressaltamos a questão da eticidade da pesquisa que tem por finalidade a proteção e o bem-estar daqueles a quem se destina nossa principal atenção, como também não podemos deixar de mencionar a questão da relação com a nossa realidade social. Assim, o que e como pesquisamos se relaciona diretamente à extensão como compromisso ético com o indivíduo e com as comunidades assistidas. Da mesma forma, não se deve permitir que se ofereça um cuidado pior aos pacientes (ou os exponhamos a um risco maior) apenas porque eles estão inseridos no contexto de uma pesquisa. A ética profissional, a que determina que devemos oferecer aos nossos pacientes o melhor cuidado possível, não pode ser negligenciada em prol de objetivos de pesquisa.

Os alunos que participam da iniciação científica, para cumprirem tal objetivo, não poderão ser nem aqueles que fazem o trabalho burocrático sem condições de participar de discussões sobre a pesquisa, nem tampouco poderão ser os pesquisadores principais. É necessário que o aluno tenha um plano de trabalho integrado ao projeto do professor. $\mathrm{O}$ aluno está em formação, não pode ainda ter autonomia plena para a realização de pesquisa no momento em que entra no grupo. Sua participação tem que ser concebida como um processo de formação em que o estudante vai adquirindo crescente autonomia/conhecimento/competência. Isto significa, inclusive, levar a sério o que está presente nas regulamentações de ética em pesquisa desde Nuremberg: pesquisa que envolva ser humano deve ser realizada por pessoa plenamente capacitada para este fim. O professor deve assumir a responsabilidade. $\mathrm{O}$ docente/orientador tem que estar efetivamente envolvido no projeto de pesquisa, posto que só assim ele irá, de fato, contribuir para a formação adequada dos estudantes, ainda que estes não pretendam seguir a carreira científica. Em tempos de hipervalorização das chamadas evidências, um médico não pode deixar de ter uma boa formação que lhe possibilite analisar o conhecimento produzido e não apenas aplicá-lo.

Nunca é demais lembrar, com nossas diretrizes curriculares, que "a aprendizagem deve ser interpretada como um caminho que possibilita ao sujeito social transformar-se e transformar seu contexto. Ela deve ser orientada pelo princípio metodológico geral, que pode ser traduzido pela ação-reflexão-ação (...). Este projeto pedagógico deverá buscar a formação integral e adequada do estudante através de uma articulação entre o ensino, a pesquisa e a extensão/assistência. Porém, deverá ter a investigação como eixo integrador que retroalimenta a formação acadêmica e a prática do médico." ${ }^{2}$

\section{REFERÊNCIAS}

1. Brasil. Lei de Diretrizes e Bases da Educação Nacional, Brasília: Biblioteca Digital da Camara dos Deputados, 2010. Disponível em http://bd.camara.gov.br/bd/bitstream/handle/bdcamara/2762/ldb_5ed.pdf

2. Brasil. Diretrizes Curriculares para o Curso de Medicina, 2001. Disponível em http://portal.mec.gov.br/cne/arquivos/pdf/CES04.pdf 